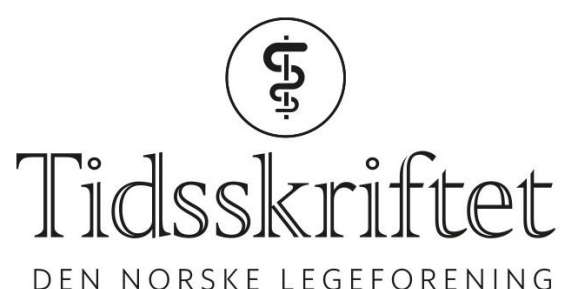

DEN NORSKE LEGEFORENING

\title{
Uønsket seksuell oppmerksomhet rettet mot leger
}

ORIGINALARTIKKEL

\section{KARIN ISAKSSON RØ}

E-post: karin.ro@legeforeningen.no

Legeforskningsinstituttet - LEFO

Hun har bidratt med ide, utforming/design, datainnsamling, tolkning av data, utarbeiding/revisjon av manus og godkjenning av innsendte manusversjon.

Karin Isaksson Rø er ph.d., MHA, spesialist i arbeidsmedisin og instituttleder. Hun har erfaring med rådgivning og kurs for leger samt med forskning om legers arbeidsforhold.

Forfatter har fylt ut ICMJE-skjemaet og oppgir ingen interessekonflikter.

\section{INGRID HJULSTAD JOHANSEN}

Uni Research Helse

Nasjonalt kompetansesenter for legevaktmedisin

Hun har bidratt med idé, utforming, analyse og tolkning av data, utarbeiding/revisjon av manus og godkjenning av innsendte manusversjon.

Ingrid Hjulstad Johansen er ph.d., spesialist i allmennmedisin og forsker II. Hun har erfaring med studier om vold og trakassering mot leger i arbeidssituasjonen.

Forfatter har fylt ut ICMJE-skjemaet og oppgir ingen interessekonflikter.

\section{JUDITH ROSTA}

Legeforskningsinstituttet - LEFO

Hun har bidratt med idé, utforming/design, datainnsamling, analyser og tolkning av data,

utarbeiding/revision av manus og godkjenning av innsendte manusversjon.

Judith Rosta er ph.d., MA og seniorforsker. Hun har erfaring med forskning om legers helse og arbeidsforhold, bl.a. initierte hun og ledet den første nasjonale spørreskjemaunders $ø$ kelsen blant sykehusleger i Tyskland.

Forfatter har fylt ut ICMJE-skjemaet og oppgir ingen interessekonflikter.

\section{BAKGRUNN}

\#MeToo-kampanjen satte søkelys på forekomst av uønsket seksuell oppmerksomhet innenfor ulike yrkesgrupper. Vi ønsket å undersøke uønsket seksuell oppmerksomhet rettet mot leger, og så på omfang og endring over tid i to representative datasett innsamlet før kampanjen.

\section{MATERIALE OG METODE}

I 1993 og 2014/15 ble det gjennomført spørreundersøkelser om arbeidsforhold, inkludert opplevd uønsket seksuell oppmerksomhet, i representative utvalg av norske leger. Disse dataene ble analysert ved sammenligning av andeler og logistisk regresjon med hensyn til kjønn og alder. 
Andelen leger som rapporterte opplevd uønsket seksuell oppmerksomhet, økte signifikant fra $2,7 \%(95 \% \mathrm{KI} 2,1-3,3)$ i 1993 til 4,6\% (3,4-5,8) i 2014/15. Det å være kvinne og å være ung ga $\emptyset \mathrm{kt}$ risiko for opplevd uønsket seksuell oppmerksomhet.

\section{FORTOLKNING}

Vi finner en økning i opplevd uønsket seksuell oppmerksomhet blant leger fra 1993 til 2015. Det kan reflektere en reell økning eller endret terskel for rapportering. I fremtidige studier bør man undersøke hvem den uønskede oppmerksomheten kommer fra, samt alvorlighetsgrad og konsekvenser av hendelsene.

I forlengelse av nettkampanjen \#MeToo har fortellinger i mediene om seksuell trakassering og uønsket seksuell oppmerksomhet rystet organisasjoner og arbeidsplasser over store deler av verden (1). Over 3600 kvinnelige leger og medisinstudenter signerte i desember 2017 et opprop mot uønsket seksuell oppmerksomhet i Aftenposten. De viste til at en av fem kvinnelige leger i en Facebook-gruppe rapporterte om egenopplevde, jobbrelaterte overgrep eller seksuell trakassering (2).

Statistisk sentralbyrås (SSBs) levekårsundersøkelser viser at andelen yrkesaktive personer som hadde opplevd uønsket seksuell oppmerksomhet minst et par ganger i måneden, økte i perioden 1989-2016, fra $4 \%$ til $7 \%$ blant kvinner og fra $1 \%$ til $2 \%$ blant menn. Yngre aldersgrupper, ansatte med skift- eller turnusarbeid og ansatte innen kultur, idrett, sykepleie og pleie- og omsorgsarbeid hadde høyere forekomst (3).

Trakassering og mobbing på arbeidsplassen fører til høyere forekomst av psykiske plager, stressreaksjoner, sykefravær og redusert jobbtilfredshet (4-6). I en metaanalyse av 41 studier om konsekvenser av uønsket seksuell oppmerksomhet fant man assosiasjoner med lavere tilfredshet, mindre organisatorisk delaktighet, høyere sykefravær og psykisk uhelse (7).

Det norske lovverket regulerer arbeidsatferd, deriblant uønsket seksuell oppmerksomhet. Likestillings- og diskrimineringsloven forbyr seksuell trakassering, definert som «uønsket seksuell oppmerksomhet som har som formål eller virkning å være krenkende, skremmende, fiendtlig, nedverdigende, ydmykende eller plagsom» (8). Arbeidsmiljøloven sier at arbeidsgiver skal «sikre et arbeidsmiljø som gir grunnlag for en helsefremmende og meningsfylt arbeidssituasjon» (9), og i Legeforeningens etiske regler står det at leger skal vise kolleger og medarbeidere respekt, og hjelpe, råde og veilede dem (10).

\#MeToo-kampanjen har satt et nødvendig søkelys på uønsket seksuell oppmerksomhet. Engasjementet bak uttalelser i mediene er stort, men tallene er ikke sikkert representative for yrkesgruppene som omtales. Vi ønsket derfor å undersøke opplevelse og utvikling av uønsket seksuell oppmerksomhet i representative utvalg av leger - før \#MeToo-kampanjen.

\section{Materiale og metode}

Data er hentet fra spørreskjemaundersøkelser i to uavhengige og tilnærmet representative utvalg av yrkesaktive leger: Legeforskningsinstituttets legekårsunders $\emptyset$ kelse i 1993 og Legepanelet i 2014/15, nærmere beskrevet i tidligere studier $(11,12)$. Ett spørsmål om uønsket seksuell oppmerksomhet var begge ganger inkludert i kartlegging av erfaringer med vold, mobbing og trakassering på arbeidsplassen. I 1993 spurte man: «Hender det at du blir utsatt for uønsket seksuell oppmerksomhet, kommentarer eller lignende?». I 2014/15 brukte man det samme spørsmålet, men la til «i jobbsammenheng». Det var fem svarkategorier fra «nei» til «ja, daglig eller nesten daglig» (tab 1). Kjønn og alder ble registrert. 
Tabell 1

Andel leger som hadde opplevd uønsket seksuell oppmerksomhet i 1993 og 2014/15, oppgitt i prosent.

\begin{tabular}{|c|c|c|c|c|c|c|}
\hline & \multirow{2}{*}{\multicolumn{3}{|c|}{$\begin{array}{l}1993 \\
\text { Hender det at du blir utsatt for } \\
\text { uønsket seksuell } \\
\text { oppmerksomhet, kommentarer } \\
\text { eller lignende? }\end{array}$}} & \multirow{2}{*}{\multicolumn{3}{|c|}{$\begin{array}{l}2014 / 15 \\
\text { Hender det at du blir utsatt for } \\
\text { uønsket seksuell } \\
\text { oppmerksomhet, kommentarer } \\
\text { eller lignende i } \\
\text { jobbsammenheng? }\end{array}$}} \\
\hline & & & & & & \\
\hline & $\begin{array}{l}\text { Kvinner } \\
(\mathrm{n}=748)\end{array}$ & $\begin{array}{l}\text { Menn } \\
(n=1839)\end{array}$ & $\begin{array}{l}\text { Totalt } \\
(\mathbf{n}=\mathbf{2 5} 57)\end{array}$ & $\begin{array}{l}\text { Kvinner } \\
(\mathrm{n}=472)\end{array}$ & $\begin{array}{l}\text { Menn } \\
(n=636)\end{array}$ & $\begin{array}{l}\text { Totalt } \\
(\mathrm{n}=1108)\end{array}$ \\
\hline $\mathrm{Nei}$ & 94,8 & 98,3 & 97,3 & 92,2 & 97,8 & 95,4 \\
\hline $\begin{array}{l}\text { Ja, inntil et par } \\
\text { ganger } \mathrm{i} \\
\text { måneden }\end{array}$ & 5,0 & 1,5 & 2,6 & 6,8 & 1,7 & 3,9 \\
\hline $\begin{array}{l}\text { Ja, omtrent én } \\
\text { gang i uken }\end{array}$ & 0,1 & 0,1 & 0,1 & 1,0 & 0,5 & 0,7 \\
\hline $\begin{array}{l}\text { Ja, et par } \\
\text { ganger i uken }\end{array}$ & 0,0 & 0,1 & 0,0 & 0,0 & 0,0 & 0,0 \\
\hline $\begin{array}{l}\text { Ja, daglig eller } \\
\text { nesten daglig }\end{array}$ & 0,1 & 0,0 & 0,0 & 0,0 & 0,0 & 0,0 \\
\hline
\end{tabular}

Vi benyttet andeler for å beskrive sentraltendens og for gruppesammenligninger mellom kjønn og aldersgrupper. Statistisk signifikans ble vurdert ut ifra om 95\%konfidensintervallene for andelene overlappet. Samtidig effekt av kjønn og alder på opplevd uønsket seksuell oppmerksomhet ble vurdert i logistiske regresjonsmodeller. Besvarelser som manglet informasjon om kjønn, alder eller opplevd uønsket seksuell oppmerksomhet, ble ekskludert fra analysene. Vi brukte Prediktiv Analyticsprogramvarestatistikk versjon 23.

\section{Resultater}

\section{RESPONDENTENE}

Det var 2628 (72,8\%) respondenter i 1993 og 1261 (78,2 \%) i 2014/15, hvorav henholdsvis 41 og 153 som ikke hadde svart på spørsmålene om opplevd uønsket seksuell oppmerksomhet, kjønn eller alder, ble ekskludert fra analysene.

Andelen kvinner $\emptyset$ kte fra 28,9\% (95\% KI 27,2-30,7; n = 748) i 1993 til 42,6\% (95\% KI 39,7-45,5; n $=472$ ) i 2014/15. Gjennomsnittlig alder var 42,2 år ( 95 \% KI 41,8-42,6) i 1993 og 48,5 år (95\% KI 47,9-49,2) i 2014/15, med spredning fra 25-69. Flertallet jobbet heltid i sykehus (data ikke vist).

\section{OPPLEVD UØNSKET SEKSUELL OPPMERKSOMHET}

Tabell 1 viser frekvenser av opplevd uønsket seksuell oppmerksomhet blant kvinnelige og mannlige leger i 1993 og 2014/15. Det var en lett økning i «ja, inntil et par ganger i måneden» og «ja, omtrent én gang i uken», samtidig som «et par ganger i uken» eller «daglig eller nesten daglig» ble rapportert av to leger i 1993 og ingen i 2014/15.

Det var en signifikant $ø$ kning i andelen som hadde opplevd uønsket seksuell oppmerksomhet minst et par ganger i måneden, fra 2,7 \% (95\% KI 2,1-3,3) i 1993 til 4,6 \% (95\%

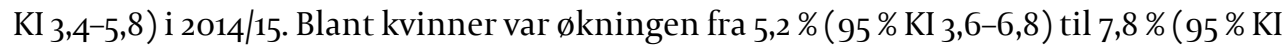
5,4-10,2) og blant menn fra 1,7\% (95\% KI 1,1-2,3) til 2,2 \% (95\% KI 1,1-3,3), men disse var ikke statistisk signifikante (fig 1). 


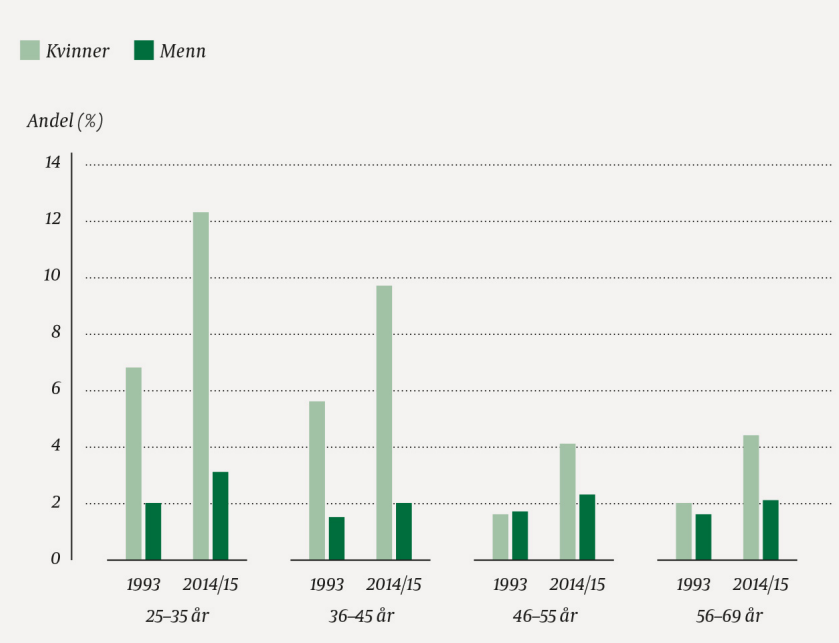

Figur 1 Andelen i prosent av kvinnelige og mannlige leger som hadde opplevd uønsket seksuell oppmerksomhet i jobbsammenheng minst et par ganger i måneden eller oftere $i 1993$ og i 2014/15, fordelt på alder. Økningen man fant $i$ alle aldersgrupper og for begge kjønn var ikke statistisk signifikant. Kvinner: $n=748$ (1993), $n=472$ (2014/15), menn: $n=1839$ (1993), $n=636(2014 / 15)$.

\section{ALDER OG KJØNN}

De logistiske regresjonsanalysene i tabell 2 viser at kvinnelig kjønn, både i 1993 og 2014/15, samt ung alder i 2014/15 var statisk signifikante prediktorer for opplevd uønsket seksuell oppmerksomhet.

\section{Tabell 2}

Effekt av kjønn og alder på opplevd uønsket seksuell oppmerksomhet inntil et par ganger i måneden eller oftere blant leger i Norge i 1993 og 2014/15.

\begin{tabular}{|lllll|}
\hline \multicolumn{2}{|c}{1993} & \multicolumn{2}{c|}{ 2014/15 } \\
\hline & OR (95\% KI) & P-verdi & OR $(\mathbf{9 5} \%$ KI $)$ & P-verdi \\
\hline Kjønn & & & & \\
\hline Mann & 1 & & 1 & \\
\hline Kvinne & $2,88(1,75-4,73)$ & $<0,001$ & $3,03(1,59-5,78)$ & $<0,001$ \\
\hline Alder (år) & $0,98(0,95-1,01)$ & 0,11 & $0,96(0,94-0,99)$ & 0,01 \\
\hline
\end{tabular}

\section{Diskusjon}

Studien viser at andelen leger som rapporterte at de hadde vært utsatt for uønsket seksuell oppmerksomhet, økte fra 1993 til 2014/15. Det var tendens til økning innen alle aldersgrupper gjennom perioden for begge kjønn, men her var tallene for små til å kunne trekke sikre konklusjoner. Kvinner var mer utsatte enn menn, og yngre kvinner var mer utsatte enn eldre kvinner.

\section{SAMMENLIGNINGER}

I november 2017 rapporterte $40 \%$ av et tilfeldig utvalg svenske kvinnelige leger at de hadde vært utsatt for seksuell trakassering eller overgrep fra pasienter, kolleger eller overordnede ledere (13), og i Aftenposten desember 2017 rapporterte 20 \% fra en Facebook-gruppe med kvinnelige leger seksuelle overgrep eller trakassering fra ansatte i helsevesenet (2). Forskjellene i forekomst, både mellom disse to studiene og i relasjon til våre tall kan skyldes flere ulike forhold.

$\emptyset \mathrm{kt}$ oppmerksomhet rundt temaet i forbindelse med \#MeToo-kampanjen og senket terskel for å melde fra, kan trolig bidra til å forklare den høyere forekomsten i disse to studiene 
sammenlignet med data fra 2015 .

Forskjellene kan også skyldes at uønsket seksuell oppmerksomhet er kartlagt ulikt i undersøkelsene. Tidligere studier viser, for eksempel, at man på direkte spørsmål om opplevelse av uønsket seksuell oppmerksomhet (med eller uten en definisjon av hva dette innebærer) finner en lavere forekomst enn hvis man konkret spør om opplevelse av en rekke definerte kommentarer og handlinger $(14,15)$.

De to rapportene fra 2017 er heller ikke nødvendigvis representative for legene som gruppe i Norge eller Sverige. Tidligere studier har vist at forskning på uønsket seksuell oppmerksomhet og trakassering er spesielt sårbar for skjevrapportering både på grunn av vansker med å definere begrepene og mangel på representative utvalg (14).

Forskjellene mellom de norske og svenske tallene fra 2017 har trolig også sammenheng med om trakasseringen eller overgrepene kom fra kolleger vs. fra kolleger og pasienter/klienter. I Levekårsundersøkelsen 2016 ble det rapportert at $79 \%$ av uønsket seksuell oppmerksomhet kom fra kunder, klienter, elever eller andre ikke-ansatte, $20 \%$ fra kolleger og $6 \%$ fra overordnede.

Tiltak mot uønsket seksuell oppmerksomhet må tilpasses til om den kommer fra ansatte eller ikke-ansatte. Ved fremtidige undersøkelser er det viktig å skille mellom disse gruppene for å kunne gi arbeidsgivere, tillitsvalgte og legegruppen som helhet et bedre grunnlag for å velge nødvendige tiltak for å redusere uønsket seksuell oppmerksomhet.

Siden vårt spørsmål om opplevd uønsket seksuell oppmerksomhet er direkte sammenlignbart med det som er stilt i Statistisk sentralbyrås levekårsundersøkelse om arbeidsmiljø ( «Utsatt for uønsket seksuell oppmerksomhet, kommentarer eller lignende, et par ganger i mnd el mer») (3), kan vi se at forekomsten blant leger var ganske lik forekomsten i befolkningen for øvrig i 2014, både for kvinner ( 7,8 \% vs. 7,0 \%) og menn (2,2 \% vs. $2,0 \%)(3)$.

Gjennom de siste 20 årene, også før \#MeToo-kampanjen, finner man en økning i uønsket seksuell oppmerksomhet, særlig blant kvinner (leger fra 5,2 \% til 7,8 \% og befolkningen fra 4,0 \% til 7,0 \%). Dette kan skyldes en gradvis endring i holdninger til og oppmerksomhet rundt dette, og kan således være et uttrykk for endringer i forståelsen av fenomenet. På den annen side har vi i denne tidsperioden ikke funnet tilsvarende endring i forekomst av mobbing eller vold, som vi kartla samtidig $(12,16)$.

Ifølge Statistisk sentralbyrå er sykepleiere mest utsatt for uønsket seksuell oppmerksomhet (3). Den store forskjellen mellom andelen sykepleiere (17\%) og kvinnelige leger (7,8\%) kan henge sammen med forskjeller i kontakt med pasienter, klienter eller pårørende. Som beskrevet ovenfor, tyder undersøkelser på at forekomsten av uønsket seksuell oppmerksomhet er høyere i yrker med utstrakt kunde- eller brukerkontakt (4).

\section{ARBEIDSKULTUR}

På samme måte som for andre typer vold og trakassering (4-6), viser studier at uønsket seksuell oppmerksomhet og seksuell trakassering er relatert til psykiske helseproblemer og til mindre tilfredshet med arbeidssituasjonen $(7,14)$. Det kan derfor være relevant å se på uønsket seksuell oppmerksomhet som en del av et større bilde på ukultur, der mobbing, utestenging og vold kan forekomme (4). En svensk studie fra 2017 viste at unge legers, særlig kvinners, valg av spesialitet kunne påvirkes av at arbeidsmiljøet på avdelingen ble oppfattet som ekskluderende og preget av machokultur i kombinasjon med uønsket seksuell oppmerksomhet (17). Også i Norge har vi studier som tyder på at ukultur på arbeidsplassen kan være styrende for valg av spesialitet (18), og vi bør undersøke om uønsket seksuell oppmerksomhet er en del av dette bildet.

\section{KJØNNSFORSKJELLER}

I likhet med mange studier har \#Metoo-kampanjen hovedsakelig fokusert på menns seksuelle trakassering av kvinner. Vår studie viser at også menn rapporterer uønsket 
seksuell oppmerksomhet, og temaet er derfor viktig for begge kjønn.

I et norsk representativt befolkningsutvalg, med lignende spørsmål som i vår studie, fant man en forskjell i forekomst på 3:1 mellom kvinner og menn (14). Dette er tilsvarende det vi fant i vår studie. I det samme utvalget fant man derimot ingen kjønnsforskjeller i antall opplevde kommentarer og handlinger (av forfatterne siden definert som uønsket seksuell oppmerksomhet). I studien diskuteres flere mulige årsaker til dette. Et viktig spørsmål er om det er skadelig å være utsatt for konkrete definerte kommentarer og handlinger hvis man ikke selv oppfatter dem som uønskede (14). Menn kan oppleve det som mer truende for selvfølelsen å definere seg selv som offer for uønsket seksuell oppmerksomhet, og dermed, bevisst eller ubevisst, underrapportere forekomst. Men den samme kommentaren eller handlingen kan også oppfattes som mer truende eller krenkende av en kvinne enn av en mann (14). Graden av krenkelse eller trussel kan også påvirkes av alder og stilling og kan være en viktig forklaring på at kvinner opplever mer uønsket seksuell oppmerksomhet enn menn, selv om antallet opplevde kommentarer og handlinger kan være likt.

Andelen yrkesaktive kvinnelige leger økte fra $29 \%$ til $43 \%$ fra 1993 til 2014/15 i våre utvalg, og har nå passert 50 \% i Norge (19). Det er viktig å følge den videre utviklingen av uønsket seksuell oppmerksomhet både blant kvinnelige og mannlige kolleger i lys av endret kjønnsbalanse.

\section{STYRKER OG SVAKHETER}

Styrker i denne studien er representative legeutvalg og relativt høy svarprosent, noe som gir pålitelige data. Bruk av samme spørsmål som Statistisk sentralbyrå (3), gir mulighet for sammenligning med befolkningen som helhet og mellom ulike yrkesgrupper.

En viktig begrensning er mangel på definisjon i spørreskjemaet både av hva uønsket seksuell oppmerksomhet betyr, og manglende opplysninger om hvem som sto bak den uønskede seksuelle oppmerksomheten (overordnede, kolleger, pasienter, andre) og om alvorlighetsgrad av handlingene. Som diskutert over, har spørremetoden stor betydning for hvilken forekomst av uønsket seksuell oppmerksomhet man finner $(14,15)$.

På tross av usikkerhet rundt punktprevalensen, vil bruk av det samme spørsmålet ved flere tidspunkt og i ulike grupper kunne vise endring over tid samt forskjeller mellom kjønn og mellom yrkesgrupper.

En mer detaljert analyse av data etter spesialitet og jobbkategorier var ikke mulig grunnet den relativt lave andelen som rapporterte uønsket seksuell oppmerksomhet.

I 2014/15 brukte vi det samme spørsmålet som ble gitt i 1993, men med tillegg «i jobbsammenheng». Den mulige innsnevringen av betydning i 2014/15 kunne ha resultert i lavere rapportering. Samtidig var spørsmålet i begge undersøkelsene plassert i en bolk der vi spurte om vold og mobbing på arbeidsplassen. Spørsmålet har derfor trolig blitt tolket på samme måte begge ganger. Spørsmålet var heller ikke presisert i forhold til tidsperiode. Siden spørsmålet plassert rett før begge gangene omhandlet forekomst av mobbing $i$ løpet av det siste året er det sannsynlig at det også i spørsmålet om uønsket seksuell oppmerksomhet ble tolket til å gjelde opplevelser siste år.

\section{Konklusjon}

Fra 1993 til 2014/15 fant vi en økning i rapportert uønsket seksuell oppmerksomhet blant norske leger. Kvinners høyere risiko for å oppleve uønsket seksuell oppmerksomhet og den $\emptyset$ kende andelen kvinnelige leger tydeliggjør nødvendigheten av å få på plass tiltak som kan redusere forekomsten. Fenomenet bør kartlegges regelmessig, med høy presisjon av hvem den uønskede seksuelle oppmerksomheten kommer fra, alvorlighetsgrad og konsekvenser av hendelsene. I hele helsesektoren, der det også er profesjonsgrupper som rapporterer enda høyere forekomst av uønsket seksuell oppmerksomhet enn leger, er det viktig å få en bedre forståelse av fenomenet, $\varnothing \mathrm{kt}$ treffsikkerhet på tiltak og bedre ivaretakelse av personer 
og miljøer som har vært utsatt for dette.

\section{HOVEDBUDSKAP}

Forekomsten av opplevd uønsket seksuell oppmerksomhet blant leger i Norge økte fra 1993 til 2014/15

Kvinnelig kjønn og ung alder økte sannsynligheten for å oppleve uønsket seksuell oppmerksomhet

I fremtidige undersøkelser bør man kartlegge hvem den uønskede oppmerksomheten kommer fra, alvorlighetsgrad og konsekvenser for den enkelte og for arbeidsmiljøet

\section{LITTERATUR:}

1. Lønning KJ. Ringer i vannet etter \#Metoo. Dagens Medisin 11.1.2018.

https://www.dagensmedisin.no/artikler/2018/o1/11/ringer-i-vannet-etter-metoo/ (28.2.2018).

2. \#utentaushetsplikt:36oo norske leger og medisinstudenter bryter tausheten. Vil stoppe

trakassering og maktmisbruk. Aftenposten 7.12.2017.

https://www.aftenposten.no/article/ap-VRbQm6.html (28.2.2018).

3. Statistisk sentralbyrå. Levekårsundersøkelsen: Arbeidsmiljø. Statistikkbanken.

https://www.ssb.no/statbank/list/arbmiljo?rxid=3a56e123-4959-4de1-891d-d3c7e242d66o (28.2.2018).

4. Normann TM, Rønning E. Konflikter, mobbing, trakassering og vold i arbeidslivet. Få utsatte, noen yrker mer utsatt enn andre. Samfunnsspeilet 2007; nr. 4: 62-71.

5. Taniguchi T, Takaki J, Hirokawa K et al. Associations of workplace bullying and harassment with stress reactions: a two-year follow-up study. Ind Health 2016; 54: 131 - 8. [PubMed][CrossRef]

6. Niedhammer I, Chastang JF, Sultan-Taïeb H et al. Psychosocial work factors and sickness absence in 31 countries in Europe. Eur J Public Health 2013; 23: 622 - 9. [PubMed][CrossRef]

7. Willness CR, Steel P, Lee K. A meta-analysis of the antecedents and consequences of workplace sexual harassment. Person Psychol 2007; 60: 127 - 62. [CrossRef]

8. LOV-2017-06-16-51. Lov om likestilling og forbud mot diskriminering (likestillings- og diskrimineringsloven): $§ 13$.

9. LOV-2005-06-17-62. Lov om arbeidsmiljø, arbeidstid og stillingsvern mv.(arbeidsmiljøloven).

10. Den norske legeforening. Etiske regler for leger: kapittel II §1.

https://legeforeningen.no/Om-Legeforeningen/Organisasjonen/Rad-og-utvalg/Organisasjonspolitiskeutvalg/etikk/etiske-regler-for-leger/(23.7.2018).

11. Aasland OG, Olff M, Falkum E et al. Health complaints and job stress in Norwegian physicians: the use of an overlapping questionnaire design. Soc Sci Med 1997; 45:1615 - 29. [PubMed][CrossRef]

12. Rosta J, Aasland OG. Perceived bullying among Norwegian doctors in 1993, 2004 and 2014-2015: a study based on cross-sectional and repeated surveys. BMJ Open 2018; 8: eo18161. [PubMed][CrossRef] 13. Wihlborg A. 40\% av kvinnliga läkare utsatta för sexuella trakasserier. Framtidens karriär - Läkare. http://karriarlakare.se/artikel/40-av-kvinnliga-lakare-utsatta-for-sexuella-trakasserier/ (28.2.2018).

14. Nielsen MB, Bjørkelo B, Notelaers G et al. Sexual harassment: Prevalence, outcomes, and gender differences assessed by three different estimation methods. J Aggress Maltreat Trauma 2010; 19: 252 - 74. [CrossRef]

15. Stark S, Chernychenko OS, Lancaster AR et al. Toward standardized measurement of sexual harassment: Shortening the SEQ-DoD using Item Response Theory. Mil Psychol 2002; 14: 49- 72. [CrossRef]

16. Johansen IH, Baste V, Rosta J et al. Changes in prevalence of workplace violence against doctors in all medical specialties in Norway between 1993 and 2014: a repeated cross-sectional survey. BMJ Open 2017; 7: e017757. [PubMed][CrossRef] 
17. Diderichsen S. It's just a job. A new generation of physicians dealing with career and work ideals. Doktoravhandling. Umeå: Institutionen för folkhälsa och klinisk medicin, Universitetet i Umeå, 2017. http://umu.diva-portal.org/smash/get/diva2:1145048/FULLTEXTo1.pdf(28.02.18).

18. Gjerberg E. Gender similarities in doctors' preferences-and gender differences in final specialisation. Soc Sci Med 2002; 54: 591 - 605. [PubMed][CrossRef]

19. Den norske legeforening. Alle yrkesforeninger samlet - medlemstall. http://legeforeningen.no/Emner/Andre-emner/Legestatistikk/Medlemsstatistikk/Yrkesforeninger/Alle -yrkesforeninger-samlet-medlemstall/ (11.2.2018).

Publisert: 15. oktober 2018. Tidsskr Nor Legeforen. DOI: 10.4045/tidsskr.18.0203

Mottatt 28.2.2018, første revisjon innsendt 18.5.2018, godkjent 23.7.2018.

(C) Tidsskrift for Den norske legeforening 2020. Lastet ned fra tidsskriftet.no 